\title{
B-type brain natriuretic peptide as marker of hemodynamic overload of the patent ductus arteriosus in the preterm infant
}

\author{
Péptido natriurético cerebral tipo B como marcador de sobrecarga hemodinámica del \\ conducto arterioso permeable en el recién nacido prematuro
}

\author{
Jose Rafael Parra-Bravo ${ }^{1 *}$, M. Teresa Valdovinos-Ponce², Heladia García ${ }^{3}$, Juan C. Núñez-Enríquez, \\ M. Lourdes Jiménez-Cárdenas², Rodrigo Avilés-Monjaraz², and Wendy Lavana-Hernández²
}

${ }^{1}$ Department of Pediatric Cardiology; ${ }^{2}$ Neonatology Department. Hospital General Tláhuac, Secretaría de Salud; ${ }^{3}$ Unit of Research in Analysis and Synthesis of Evidence, Centro Médico Nacional (CMN) Siglo XXI, Instituto Mexicano del Seguro Social (IMSS); ${ }^{4}$ Clinical Epidemiology Research Unit (UMAE), Children's Hospital, CMN Siglo XXI Dr. Silvestre Frenk Freund, IMSS. Mexico City, Mexico

\begin{abstract}
Introduction: The echocardiogram is the gold standard, in the diagnosis of the hemodynamically significant patent ductus arteriosus (hs-PDA) of the premature newborn (PNB). Type B brain natriuretic peptide (BNP) may be useful in the diagnosis and management of CAP-hs. Objective: The objective of the study was to assess the utility of BNP as a marker of hemodynamic overload of the patent ductus arteriosus in newborns with gestational age $<32$ weeks or weight $<1500 \mathrm{~g}$, and to identify the best cutoff point for BNP levels that would best predict a PDA with hemodynamic impact requiring pharmacological and/or surgical treatment. Methods: Retrospective, observational, and descriptive study of $P N B<32$ weeks gestation or weight $<1500 \mathrm{~g}$, in which echocardiogram and BNP determination was performed. Analysis of the global sample and by subgroups, depending on the hs-PDA status was performed. Results: A total of 29 patients were analyzed. A significant correlation was found between the PDA/weight ratio and BNP levels (Spearman: 0.71; 95\% confidence interval: 0.45-0.87; $p<0.001$ ). The best BNP cutoff point to predict CAP-hs was $486.5 \mathrm{pg} / \mathrm{ml}$ with a sensitivity of $81 \%$ and specificity of $92 \%$ $(p<0.001)$. Conclusion: The BNP cutoff point identified in the present study was correlated with the presence of CAP-hs.
\end{abstract}

Key words: Patent ductus arteriosus. México. B-type natriuretic peptide. Prematurity.

\section{Resumen}

Introducción: El ecocardiograma es el método de referencia para el diagnóstico del conducto arterioso permeable (CAP) hemodinámicamente significativo (CAP-hs) del recién nacido prematuro (RNP). El péptido natriurético tipo $B(B N P)$ puede ser útil en el diagnóstico y el manejo del CAP-hs. Objetivo: Evaluar la utilidad del BNP como marcador de sobrecarga hemodinámica del conducto arterioso permeable en el RNP con edad gestacional < 32 semanas o peso < 1500 gramos, e identificar el mejor punto de corte para los valores de BNP que mejor prediga un CAP con repercusión hemodinámica que requiera tratamiento farmacológico o quirúrgico. Método: Estudio retrospectivo, observacional y descriptivo de RNP $<32$ semanas de gestación o peso < 1500 gramos en los que se realizó ecocardiograma y determinación del BNP. Análisis

Correspondence:

*José Rafael Parra-Bravo

E-mail: rpb.cardioped@gmail.com
Available online: 18-05-2021

Date of reception: $16-12-2019$

DOI: 10.24875/ACME.M21000172
Arch Cardiol Mex (Eng). 2021;91(1):16-23 www.archivoscardiologia.com license (http://creativecommons.org/licenses/by-nc-nd/4.0/). 
de muestra global y por subgrupos, en función del CAP-hs. Resultados: Se analizaron 29 pacientes. Se encontró una correlación significativa entre la relación CAP/peso y los valores del BNP (prueba de Spearman: 0.71; intervalo de confianza del 95\%: 0.45-0.87; $p<0.001$ ). El mejor punto de corte del BNP para predecir CAP-hs fue $486.5 \mathrm{pg} / \mathrm{ml}$, con una sensibilidad del $81 \%$ y una especificidad del $92 \%$ ( $p<0.001)$. Conclusión: El punto de corte del BNP identificado en el presente estudio se correlacionó con la presencia de CAP-hs.

Palabras clave: Conducto arterioso permeable. México. Péptido natriurético tipo B. Prematuridad.

\section{Introduction}

Patent ductus arteriosus (PDA) has been associated with significant morbidity in premature newborns (PNB), and especially in those of very low-birth weight. In hemodynamically significant PDA (hs-PDA), there is an important shunt from the systemic to the pulmonary circuit, which results in increased pulmonary blood flow and reduced systemic blood flow. Diastolic steal in systemic circulation can lead to a high risk of intraventricular hemorrhage, necrotizing enterocolitis and renal perfusion abnormalities ${ }^{1}$. Increased pulmonary blood flow contributes to respiratory distress syndrome worsening and later to bronchopulmonary dysplasia.

The appearance of symptoms depends on the magnitude of the left-right shunt across the PDA and on PNB's capacity to handle volume overload. Clinical findings, such as continuous murmur and bounding pulses, are not always present, especially in PNBs with very low birth weight and ventilatory support, where PDA could be "silent." To date, clinical and radiological evaluations used to diagnose hs-PDA have substantial limitations, and hs-PDA early treatment in PNBs has been shown to improve symptomatology, reduce ventilatory support duration, decrease the need for surgical ligation, and shorten hospital stay days ${ }^{2,3}$.

At present, echocardiography is considered the reference method for the diagnosis of hs-PDA and plays an essential role in the assessment and impact of PNB circulation, as well as in the design of treatment options. There is a clear consensus on the echocardiographic criteria that must be evaluated ${ }^{4}$.

Natriuretic peptides are synthesized and released within blood circulation by cardiomyocytes, with natriuretic, and vasodilator properties ${ }^{5}$. B-type brain natriuretic peptide (BNP) is synthesized in the heart ventricles and released in response to volume and pressure overload, and for this reason, it plays an important role in regulating extracellular fluid volume ${ }^{6}$. It has been studied as a possible marker in the diagnosis and management of hs-PDA? BNP values determination within the $1^{\text {st }}$ days of life have been shown to likely be useful to assess hemodynamic compromise and contribute to decision-making. However, the suggested BNP values in these studies are within a wide range, which makes it difficult for an absolute cutoff point to be defined ${ }^{8-10}$. There is scarce information about BNP normative values in PNBs without PDA, which makes it difficult to determine whether prematurity and its comorbidity, such as respiratory distress syndrome, immature myocardium, and other conditions have an effect on BNP serum concentrations ${ }^{11,12}$. BNP values are higher within the first 3 days of life, with figures higher in PNBs than in term newborns, but they progressively decrease and are similar by 1 month of age $\mathrm{e}^{13-15}$.

The primary objective of the present study was to evaluate the usefulness of BNP as a marker of PDA hemodynamic overload in PNBs with gestational age $<32$ weeks or weight $<1500 \mathrm{~g}$. The secondary objective was to identify the best cutoff point for serum BNP concentrations, which best predicts a PDA with hemodynamic repercussions that requires pharmacological or surgical treatment, or both.

\section{Method}

\section{Patients}

Retrospective, descriptive, and observational study carried out at the neonatal intensive care unit (NICU) of the Tláhuac General Hospital, Mexico City Ministry of Health, within the period comprised between July 2018 and June 2019. Twenty-nine newborns were included (16 females and 13 males) with a gestational age $<32$ weeks and birth weight $<1500 \mathrm{~g}$, within the first $24 \mathrm{~h}$ of birth. Newborns with major congenital heart defects, chromosomal abnormalities, confirmed sepsis, kidney failure, persistent pulmonary hypertension, and death within 3 days after NICU admission were excluded from the study. The study was approved by the institutional research committee and informed consent was obtained from the parents. 


\section{Echocardiogram}

All PNBs included in the study underwent a transthoracic echocardiogram with two-dimensional color Doppler between the $3^{\text {rd }}$ and $5^{\text {th }}$ days of life to evaluate the PDA and rule out congenital heart disease. A Phillips 5500 ultrasound system (Phillips Medical Systems, NA, Bothell, WA) with an $8 \mathrm{MHz}$ transducer that incorporates color flow and continuous and pulsed wave Doppler was used. If PDA was observed, the maximum constriction point of the color jet flow was measured in millimeters, to assess the ductus size. A significant PDA was demonstrated by echocardiography taking into account the presence of ductal flow, with left-toright shunt (transductal gradient $<20 \mathrm{mmHg}$ ), and retrograde flow in the descending aorta (Ao). To estimate the magnitude of the left-to-right shunt across the PDA, left atrium (LA) and aortic root diameters were measured in the short axis parasternal view at the level of the aortic valve, and the LA/Ao ratio was calculated. Left ventricular dimensions were measured during systole and diastole to calculate systolic function by fractional shortening and ejection fraction. Tricuspid regurgitant flow was measured to calculate pulmonary artery systolic pressure, and a subcostal sagittal view was used to obtain images of the superior mesenteric artery. PDA evaluation was carried out taking into account the Neonatologist Performed Echocardiography and the American Society of Echocardiography recommendations $\mathrm{s}^{4,16,17}$.

hs-PDA was diagnosed if the PNB met the echocardiographic criteria and had at least three of the following six clinical signs of cardiovascular dysfunction: (1) systolic or continuous murmur at left parasternal border; (2) precordial hyperactivity; (3) peripheral bounding pulses; (4) tachycardia at rest; (5) unexplained respiratory status deterioration; and (6) increased pulmonary flow and cardiomegaly or signs of pulmonary edema on chest X-ray. Echocardiographic criteria were ${ }^{4,16}$ : (1) PDA diameter > $1.5 \mathrm{~mm}$; (2) LA/Ao ratio > 1.4; (3) diastolic turbulence (left-to-right shunt) on pulmonary artery Doppler; (4) PDA diameter/weight ratio $>1.4 \mathrm{~mm} / \mathrm{kg}$; (5) retrograde flow $>30 \%$ of diastole in the descending Ao; and (6) transductal Doppler velocity $<2 \mathrm{~m} / \mathrm{s}$. Measurements were made by a single observer, pediatric cardiologist echocardiographer with 20 years of experience in this technique. Intra-observer agreement assessed by the Kappa index in the present study was $100 \%$ in a subsample of 15 examinations. PNB with hs-PDA were treated with paracetamol, ibuprofen or surgery, depending on their clinical status (intervention group). A second echocardiogram was performed $72 \mathrm{~h}$ later to determine if there were treatment-associated changes.

\section{Plasma BNP concentration measurement}

Blood samples $(0.5 \mathrm{~mL})$ were taken for plasma BNP measurement by arterial or venous catheter aspiration, or by venous blood sampling together with other usual blood samples to avoid additional punctures and excessive blood sampling. Blood was collected coinciding in time with the transthoracic echocardiogram. The samples were analyzed with the BNP diagnostic kit (Alere ${ }^{\mathrm{TM}}$ Triage ${ }^{\circledR}$ BNP assay; Werfen Co, IL, USA) and the results were expressed in $\mathrm{pg} / \mathrm{mL}$.

In patients with suspected PDA, consultation with the pediatric cardiology department was carried out to corroborate the diagnosis, and the echocardiographic examination operator reported the results, issuing therapeutic recommendations. Data including changes in body weight, cardiorespiratory status and fluid intake and output were collected every other day, and data on length of stay and prevalence of necrotizing enterocolitis, bronchopulmonary dysplasia, intraventricular hemorrhage, and mortality were collected from medical records and from the NICU database.

\section{Statistical analysis}

Descriptive analysis was performed using the SPSS statistical package (Statistics for Windows, version 20.0), with central tendency (mean, median), and dispersion measures calculations (standard deviation, and interquartile ranges [IQR]) for quantitative variables according to the type of distribution, and frequencies and percentages for qualitative variables. Data distribution was evaluated by visualization in relation to the histogram, as well as according to skewness and kurtosis values and the Shapiro-Wilk test, with $p<0.05$ being regarded as nonparametric distribution. We used Fisher's exact test to compare categorical variables, and Mann-Whitney's U-test to compare continuous variables. For the comparison of subgroups, Mann-Whitney's U-test was used. $p<0.05$ was considered for establishing statistical significance. Spearman's test $\left(r_{s}\right)$ was used to correlate BNP values and echocardiographic findings. Finally, using receiver operating characteristic (ROC) curves, the best cutoff point for BNP values associated with hs-PDA was identified. The area under the curve (AUC), sensitivity, and specificity were determined for the best cutoff point. 


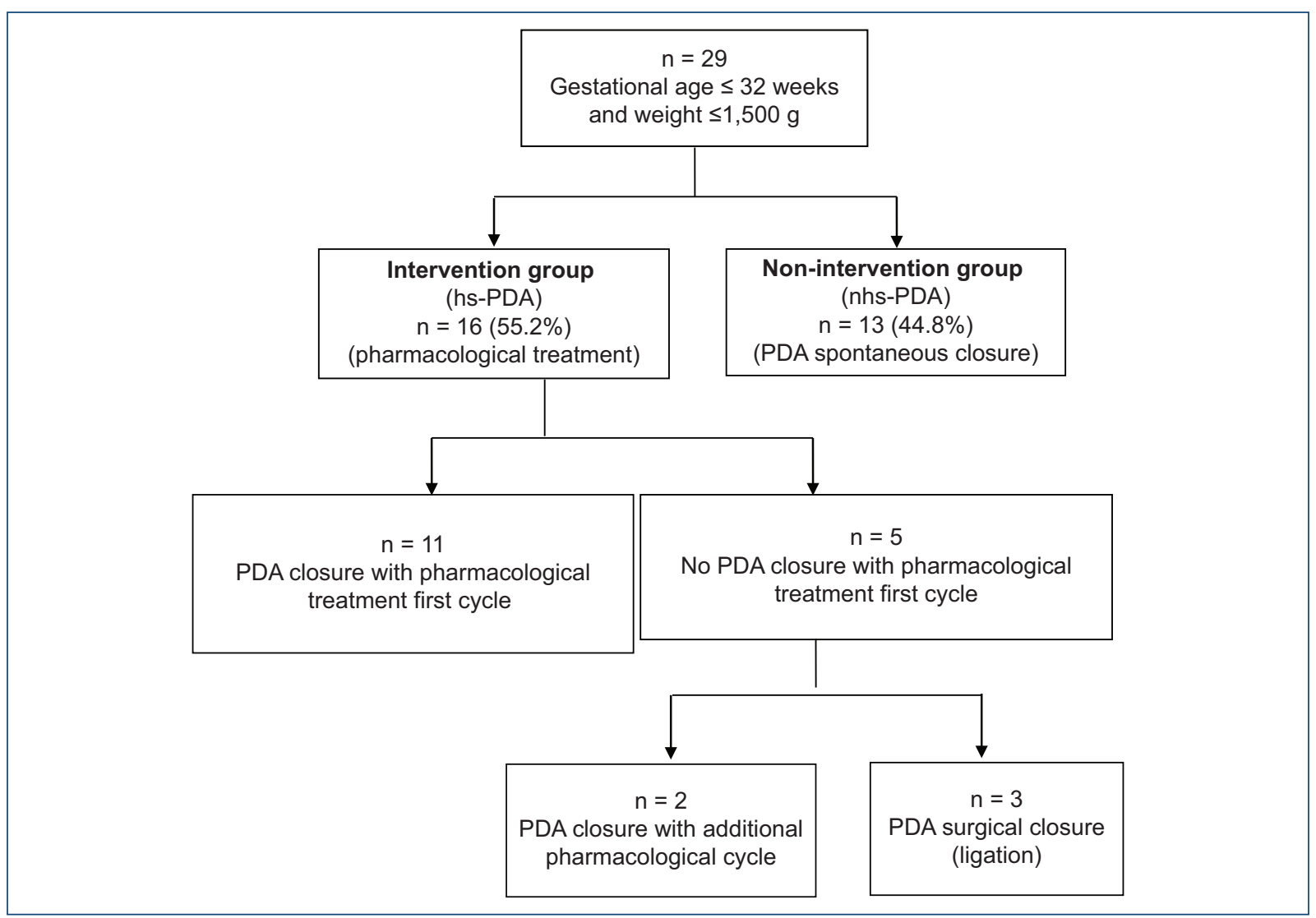

Figure 1. Study-included patients flowchart PDA: patent ductus arteriosus; hs-PDA: hemodynamically significant PDA; nhs-PDA: non-hemodynamically significant PDA.

\section{Results}

During the study period, a sample of 29 PNBs, with median gestational age of 29.0 weeks (IQR: 3.9) and birth weight of $1,080 \mathrm{~g}$ (IQR: 350), was obtained. Patient demographics and clinical characteristics are displayed in table 1, whereas the diagnostic-therapeutic algorithm is shown in figure 1.

Patients were divided in two subgroups: the first one corresponded to 16 patients with hs-PDA (median gestational age: 27.6 weeks; median weight: $990 \mathrm{~g}$ ) and the second had 13 patients with non-hs-PDA (nhsPDA) (median gestational age: 29.0 weeks; median weight: $1210 \mathrm{~g}$ ). There were no significant differences between the subgroups in data related to gestational age, birth weight, gender, antenatal steroid use, administered fluids, systemic systolic pressure, or type of delivery.

Median BNP value for the entire group $(n=29)$ was $473 \mathrm{pg} / \mathrm{mL}$ (IQR: 661.5) and BNP concentration in the subgroup with hs-PDA was significantly higher than in the subgroup with nhs-PDA (median of 751 vs.
$121 \mathrm{pg} / \mathrm{mL} ; \mathrm{p}=0.0001)$. In addition, statistical significance was observed in the 5-min Apgar, diastolic blood pressure, descending Ao diastolic steal, PDA diameter, and PDA/weight in kilograms ratio variables. As previously mentioned, cases with pulmonary hypertension, sepsis, or congenital heart disease were excluded due to a possible hs-PDA-unrelated BNP value increase.

A total of $71.7 \%$ of the patients showed PDA in the first echocardiographic evaluation, with a significant correlation between echocardiographic findings and baseline BNP value (Table 2). A positive correlation was observed between PDA/weight ratio and BNP value $\left(r_{s}=0.71 ; 95 \%\right.$ confidence interval [Cl]: 0.45-0.87; $p<0.001$ ) (Fig. 2). The best cutoff point for BNP to predict hs-PDA was $486.5 \mathrm{pg} / \mathrm{mL}$, with a sensitivity of $81 \%$, specificity of $92 \%$, and AUC of $0.93(95 \%$ Cl: 0.84-1.0; $p<0.001$ ) (Fig. 3).

Patients in the hs-PDA subgroup $(n=16)$ received intervention (pharmacological closure or surgery): ten with ibuprofen $(62.5 \%)$, six with paracetamol (37.5\%) 
Table 1. Preterm newborns demographic data and clinical parameters and comparison of variables between subgroups

\begin{tabular}{|c|c|c|c|c|}
\hline Parameter & Total group ( $n=29$ ) & hs-PDA subgroup & nhs-PDA subgroup & $\mathbf{p}$ \\
\hline Gestational age (weeks)* & $29.0(3.9)$ & $27.6(5.3)$ & $29.0(2.5)$ & 0.46 \\
\hline Birth weight $(\mathrm{g})^{*}$ & $1080(350)$ & $990(403)$ & $1210(313)$ & 0.27 \\
\hline Female gender ${ }^{\dagger}$ & $17(58.6)$ & $9(56.3)$ & $8(61.5)$ & 0.77 \\
\hline Antenatal steroid use ${ }^{\dagger}$ & $15(51.7)$ & $7(43.8)$ & $8(61.5)$ & 0.34 \\
\hline Cesarean section $^{\dagger}$ & $24(82.7)$ & $4(25)$ & $1(7.7)$ & 0.61 \\
\hline 5-min Apgar* & $8(1.0)$ & $8(1.0)$ & $9(1.0)$ & 0.002 \\
\hline Systolic BP $(\mathrm{mmHg})^{\ddagger f}$ & $54 \pm 9$ & $53 \pm 7$ & $55 \pm 9$ & 0.32 \\
\hline Diastolic BP $(\mathrm{mmHg})^{\ddagger}$ & $33 \pm 8$ & $28 \pm 6$ & $35 \pm 8$ & 0.001 \\
\hline Diastolic steal in DAo $<30 \%^{\dagger}$ & $18(62.1)$ & $14(87.5)$ & $4(30.8)$ & 0.002 \\
\hline Fluid intake $(\mathrm{ml} / \mathrm{kg} / \text { day })^{\ddagger}$ & $147 \pm 31$ & $159 \pm 36$ & $142 \pm 29$ & 0.07 \\
\hline PDA diameter (mm) & $\begin{array}{l}2.1(1.58)^{*} \\
2.2 \pm 0.9^{\ddagger}\end{array}$ & $\begin{array}{c}2.8(0.95)^{*} \\
2.84 \pm 0.69^{\ddagger}\end{array}$ & $\begin{array}{c}1.3(0.68)^{*} \\
1.42 \pm 0.41^{\ddagger}\end{array}$ & 0.0001 \\
\hline PDA/weight ratio $(\mathrm{kg})$ & $\begin{array}{c}1.6(1.93)^{*} \\
1.99 \pm 1.14^{\ddagger}\end{array}$ & $\begin{array}{l}2.81(1.97)^{*} \\
2.69 \pm 1.1^{\ddagger}\end{array}$ & $\begin{array}{l}1.02(0.51)^{*} \\
1.13 \pm 0.29^{\ddagger}\end{array}$ & 0.0001 \\
\hline Serum BNP value $(\mathrm{pg} / \mathrm{mL})$ & $\begin{array}{l}473(661.5)^{*} \\
684 \pm 890.1^{f}\end{array}$ & $\begin{array}{c}751(817)^{*} \\
1061.9 \pm 105.7^{£}\end{array}$ & $\begin{array}{l}121.0(284.2)^{*} \\
219.9 \pm 227.8^{f}\end{array}$ & 0.0001 \\
\hline
\end{tabular}

BNP: type-B brain natriuretic peptide; BP: blood pressure; DAo: descending aorta; hs-PDA: hemodynamically significant PDA; nhs-PDA: non-hemodynamically significant PDA; PDA: patent ductus arteriosus.

*Median (interquartile range)

${ }^{\dagger}$ Number $(\%)$.

${ }^{\ddagger}$ Mean ( \pm standard deviation).

Table 2. Correlation between B-type brain natriuretic peptide serum values and echocardiographic variables

\begin{tabular}{|l|c|c|}
\hline $\begin{array}{l}\text { Echocardiographic } \\
\text { parameters }\end{array}$ & $\begin{array}{c}\text { Correlation with BNP } \\
\text { baseline values }(\mathbf{p g} / \mathrm{mI}) \\
\mathbf{r}_{\mathbf{2}}(95 \% \mathbf{C I})\end{array}$ & $\mathbf{P}$ \\
\hline LA/Ao ratio & $0.64(0.38-0.81)$ & $<0.001$ \\
\hline PAD diameter & $0.66(0.23-0.91)$ & 0.007 \\
\hline DAo diameter & $0.03(-0.47-0.56)$ & 0.91 \\
\hline PAD/DAo ratio & $0.84(0.49-0.96)$ & $<0.001$ \\
\hline PAD/weight in kg ratio & $0.71(0.45-0.87)$ & $<0.001$ \\
\hline PAD gradient & $0.11(-0.56-0.73)$ & 0.69 \\
\hline LVOT flow/SMA flow ratio & $0.45(-0.08-0.80)$ & 0.09 \\
\hline MV/TV flow ratio & $0.11(-0.40-0.68)$ & 0.69 \\
\hline DAo diastolic steal & $0.35(-0.25-0.83)$ & 0.20 \\
\hline PASP $\times$ TRI & $0.61(0.06-0.87)$ & 0.01 \\
\hline
\end{tabular}

BNP: type-B brain natriuretic peptide; Cl: confidence interval; DAo: descending aorta; LA/Ao: left atrium/aorta; LVOT: left ventricular outflow tract; MV: mitral valve; PASP $\times$ TRI: pulmonary artery systolic pressure by tricuspid regurgitation index; PDA: patent ductus arteriosus; rs: Spearman's test; SMA: superior mesenteric artery; TV: tricuspid valve. and, finally, three patients required surgical ligation due to pharmacological treatment failure. PDA pharmacological closure was achieved with the first cycle in 11 patients (68.7\%), while in two patients closure was achieved with a second cycle (Fig. 1). In patients with hs-PDA ( $n=16$ ), a significant drop was observed between BNP median baseline and final values (751.50; IQR: 817 vs. 211.5 ; IQR: $268 \mathrm{pg} / \mathrm{mL}$, respectively; $p=0.01$ ), with a percentage decrease of $69.5 \pm 18.3 \%$. In patients who required surgical intervention, median baseline BNP was almost 3 times higher (1800; IQR: $2,940 \mathrm{pg} / \mathrm{mL}$ ) in comparison with those who only required pharmacological treatment (630; IQR: $394.5 \mathrm{pg} / \mathrm{mL}$ ).

Patients in the nhs-PDA subgroup (without intervention) showed a similar and progressive decline in BNP baseline and final median values (630; IQR: 394.5 vs. 172.0; IQR: $224 \mathrm{pg} / \mathrm{mL}$, respectively; $p=0.002$ ), with a percentage decrease of $69.5 \pm 19.1 \%$. PDA spontaneous closure was corroborated by echocardiography, with a mean age of 2.1 weeks. 


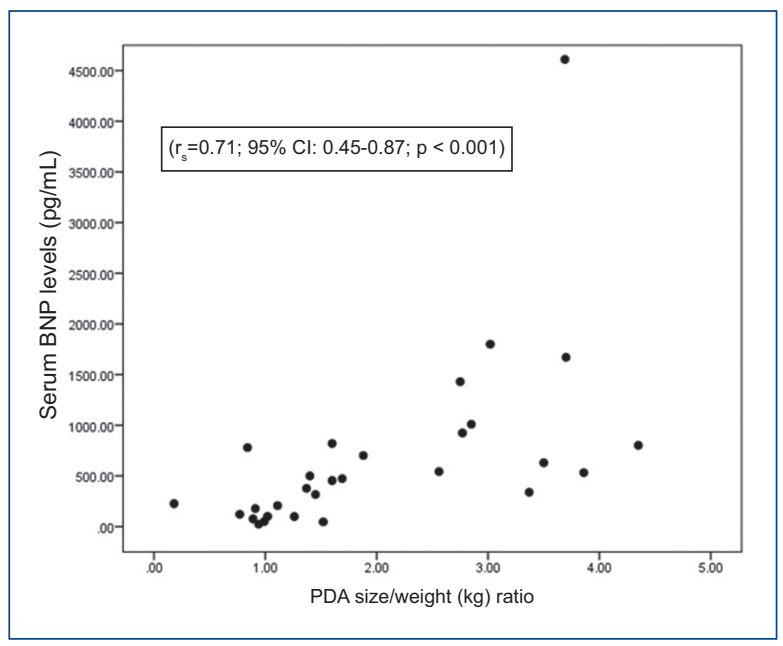

Figure 2. Positive correlation between $\mathrm{PDA} /$ weight ratio and B-type brain natriuretic peptide value. BNP: B-type brain natriuretic peptide; $\mathrm{Cl}$ : confidence interval; PDA: patent ductus arteriosus; $r_{s}$ : Spearman's test.

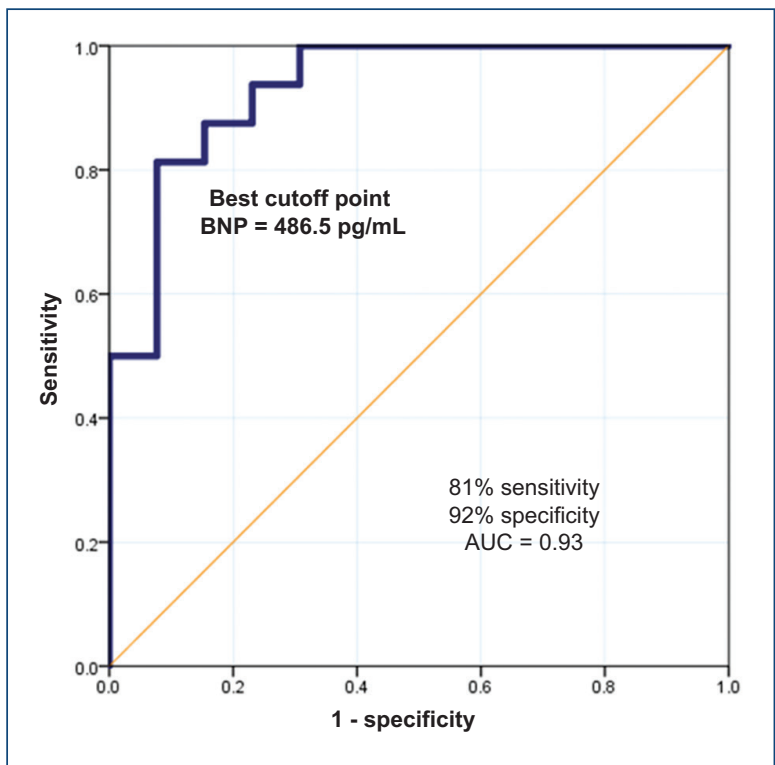

Figure 3. B-type brain natriuretic peptide serum value ROC curve in preterm newborns with hemodynamically significant patent ductus arteriosus (hs-PDA). A cutoff point of $486.5 \mathrm{~g} / \mathrm{mL}$ was calculated for detecting hs-PDA, based on the ROC curve. BNP: B-type brain natriuretic peptide; AUC: area under the curve.

\section{Discussion}

Despite PDA high prevalence, in $60-70 \%$ of PNBs, and especially in those with very low birth weight, there are no universally accepted methods to diagnose hsPDA, which increases the risk for the development of pathologies that are typical of this population and are an important cause of morbidity and mortality ${ }^{3}$. One of the main reasons for this situation is the dynamic nature of ductal tissue and its varied sensitivity to vasoconstrictor and vasodilator substances in the PNB. In addition, the factors that alter pulmonary and vascular systemic resistance can influence the degree of ductal shunt, regardless of its size $e^{15,18}$. Strategies to achieve its closure are still debated, and controversy continues on treatment criteria and the ideal moment for it to be implemented ${ }^{19-21}$.

PNBs with hs-PDA may not develop clinical signs and, if they develops them, it is usually after the $3^{\text {rd }}$ day of life, when lung disease improves ${ }^{1-3,18}$. Due to the delay in the appearance of clinical symptoms, various authors have proposed systematic screening with echocardiography at 48-72 $\mathrm{h}$ of life, taking into account that echocardiographic examination should include PDA characteristics evaluation, pulmonary overcirculation rates under left ventricular load conditions and systemic hypoperfusion indices ${ }^{4}$. At present, echocardiography is the most widely used method to detect hs-PDA in PNBs ${ }^{4,16,17}$. In this work, $71.7 \%$ of the patients showed PDA in the first echocardiogram, a figure that is higher than that reported ${ }^{22}$.

Some studies have evaluated the potential use of natriuretic peptides (cardiac markers) in pediatric and neonatal medicine ${ }^{5}$. Although BNP does not replace the echocardiogram in PDA diagnosis, it may obviate the need for repeated echocardiograms to confirm post-treatment ductal closure ${ }^{9,23}$. BNP values in PNBs are higher than in those born at term during the $1^{\text {st }}$ days after birth ${ }^{9-12}$. Their measurement is a method that provides immediate and valuable information for PDA diagnosis and management in PNBs, since values are higher in the presence of significant PDA $^{13,15}$.

Various authors refer that BNP could be a reliable parameter to predict the absence or presence of $\mathrm{PDA}^{9-12}$; in our sample, a strong association was found between BNP values and the presence of PDA. In this work, $55.2 \%$ of patients showed a hs-PDA with BNP figures higher to those found in those with nhsPDA within the first 3-5 days of life ${ }^{23-25}$. PNBs without PDA or with nhs-PDA show considerable variations in BNP blood concentration, with a maximum peak at 24-48 $\mathrm{h}$ of life and a subsequent drop towards the $5^{\text {th }}$ day of life ${ }^{13-15}$. When PDA is present in PNBs, BNP 
concentration is higher and reflects the magnitude of the shunt across the PDA, and BNP can be regarded as being able to differentiate those with hemodynamic involvement ${ }^{10-12,25}$. However, one of the limitations of the present work was that only the BNP values were evaluated and not those of $\mathrm{N}$-terminal pro-B-type natriuretic peptide (NT-proBNP), which is known to have higher sensitivity and specificity ( 88 and $92 \%$ vs. 90 and $84 \%$, respectively) ${ }^{8}$. However, in light of the findings of the present work, the possibility for the identified associations to be even stronger if assessed with the NT-proBNP marker in PNBs can be assumed ${ }^{24}$.

A ROC curve could be developed to calculate BNP cutoff point and predict hs-PDA. The best BNP cutoff value was $486.5 \mathrm{pg} / \mathrm{mL}$, with a sensitivity of $81 \%$, specificity of $92 \%$ and AUC of 0.93 (95\% Cl: $0.84-1.0$; $p<0.001$ ). Flynn et al. ${ }^{9}$ showed that the best cutoff value for BNP was $300 \mathrm{pg} / \mathrm{mL}$. A systematic review to assess BNP diagnostic safety in hs-PDA mentions the wide variety of patient and assay characteristics, with various diagnosis- and treatment-predictive cutoff values $^{8}$.

In line with other series ${ }^{6,22-25}$, we observed that the percentage decrease in BNP values were well correlated with pharmacological PDA closure, reliably predicting whether this drop is significant. Furthermore, we confirmed that BNP very high and initial figures are related to a higher incidence of duct ligation, although clinical usefulness to predict surgical treatment looks limited $26-28$.

\section{Conclusions}

Serum BNP concentrations were related to the hemodynamic overload produced by PDA in PNBs. An optimal BNP cutoff point could be identified with good sensitivity and specificity to predict hs-PDA.

The presence of BNP elevation supported the echocardiographic data and the need for medical or surgical treatment, and its decline informed of the good sensitivity BNP values show after PDA closure. Although echocardiography will remain the main diagnostic method, our findings allow proposing BNP as an additional tool in PDA diagnosis and evolutionary follow-up.

\section{Funding}

The authors did not receive any type of sponsorship to carry out this study.

\section{Conflicts of interest}

The authors declare that they have no conflicts of interest.

\section{Ethical disclosures}

Protection of human and animal subjects. The authors declare that no experiments were performed on humans or animals for this research.

Confidentiality of data. The authors declare that they have followed the protocols of their work center on the publication of patient data.

Right to privacy and informed consent. The authors declare that no patient data appear in this article.

\section{References}

1. Hamrick SE, Hansmann G. Patent ductus arteriosus of the preterm infant. Pediatrics. 2010;125:1020-30.

2. Sasi A, Deorari A. Patent ductus arteriosus in preterm infants. Indian Pediatr. 2011;48:301-8.

3. Benitz WE; Committee on Fetus and Newborn, American Academy of Pediatrics. Patent ductus arteriosus in preterm infants. Pediatrics. 2016; 137:10.1542/peds.2015-3730.

4. van Laere D, van Overmeire B, Gupta S, El-Khuffash A, Savoia M, McNamara PJ, et al. Application of neonatologist performed echocardiography in the assessment of a patent ductus arteriosus. Pediatr Res. 2018;84:S46-S56.

5. Levin ER, Gardner DG, Samson WK. Natriuretic peptides. N Engl J Med. 1998;339:321-8.

6. Chen S, Tacy T, Clyman R. How useful are B-type natriuretic peptide measurements for monitoring changes in patent ductus arteriosus shunt magnitude? J Perinatol. 2010;30:780-5.

7. Choi BM, Lee KH, Eun BL, Yoo KH, Hong YS, Son CS, et al. Utility of rapid $B$-type natriuretic peptide assay for diagnosis of symptomatic patent ductus arteriosus in preterm infants. Pediatrics. 2005; 115:e255-61.

8. Kulkarni M, Gokulakrishnan G, Price J, Fernandes C, Leeflang M, Pammi M. Diagnosing significant PDA using natriuretic peptides in preterm neonates: a systematic review. Pediatrics. 2015;135:e510-25.

9. Flynn PA, da Graca RL, Auld PA, Nesin M, Kleinman CS. The use of a bedside assay for plasma B-type natriuretic peptide as a biomarker in the management of patent ductus arteriosus in premature neonates. $J$ Pediatr. 2005;147:38-42.

10. Sanjeev S, Pettersen M, Lua J, Thomas R, Shankaran S, L'Ecuyer T. Role of plasma B-type natriuretic peptide in screening for hemodynamically significant patent ductus arteriosus in preterm neonates. J Perinatol. 2005;25:709-13

11. Puddy VF, Amirmansour C, Williams AF, Singer DR. Plasma brain natriuretic peptide as a predictor of haemodynamically significan patent ductus arteriosus in preterm infants. Clin Sci (Lond). 2002; 103:75-7.

12. Holmström H, Hall C, Thaulow E. Plasma levels of natriuretic peptides and hemodynamic assessment of patent ductus arteriosus in preterm infants. Acta Paediatr. 2001;90:184-91.

13. Mannarino S, Garofoli F, Mongini E, Cerbo RM, Codazzi AC, Tzialla C, et al. BNP concentrations and cardiovascular adaptation in preterm and fullterm newborn infants. Early Hum Dev. 2010;86:295-8.

14. Koch $A$, Singer $H$. Normal values of $B$ type natriuretic peptide in infants, children and adolescents. Heart. 2003;89:875-8.

15. Tauber KA, Doyle R, Granina E, Munshi U. B-type natriuretic peptide levels normalise in preterm infants without a patent ductus arteriosus by the fifth postnatal day. Acta Paediatrica. 2016;105:e352-5.

16. Skelton R, Evans N, Smythe J. A blinded comparison of clinical and echocardiographic evaluation of the preterm infant for patent ductus arteriosus. J Paediatr Child Health. 1994;30:406-11.

17. Chiruvolu A, Punjwani $P$, Ramaciotti $C$. Clinical and echocardiographic diagnosis of patent ductus arteriosus in premature neonates. Early Hum Dev. 2009;85:147-9. 
18. Selimer A, Bjerre JV, Schmidt MR, McNamara PJ, Hjortdal VE, Host B, et al. Morbidity and mortality in preterm neonates with patent ductus arteriosus on day 3. Arch Dis Fetal Neonatal Ed. 2013;98:F505-10.

19. Noori S. Patent ductus arteriosus in the preterm infant: treat or not treat? J Perinatol. 2010;30(Suppl):531-7.

20. Urquhart DS, Nicholl RM. How good is clinical examination at detecting a significant patent ductus arteriosus in the preterm neonate? Arch Dis Child. 2003:88:85-6.

21. Sehgal A, McNamara PJ. Does echocardiography facilitate determination of hemodynamic significance attributable to the ductus arteriosus? Eur Pediatr. 2009;168:907-14.

22. Acevedo-Olguín AL, Hernández-Benítez R, Iglesias-Leboreiro J, Bernárdez-Zapata I, Gerardo-Del Hoyo MN, Rendón Macías ME. Functional echocardiography as a tool for the dynamic treatment evaluation in critically ill neonates. Arch Cardiol Mex. 2019;89:393-8.

23. Kim JS, Shim EJ. B-type natriuretic peptide assay for the diagnosis and prognosis of patent ductus arteriosus in preterm infants. Korean Circ J.2012;42:192-6.
24. Montaner A, Galve Z, Fernández C, Jiménez L, Samper MP, Rite S. Utilidad del propéptido natriurético cerebral en el diagnóstico y manejo del ductus arterioso permeable. Ann Pediatr. 2017;86:321-8.

25. Mine K, Ohashi A, Tsuji S, Nakashima J, Hirabayashi M, Kaneko K. B-type natriuretic peptide for assessment of haemodynamically significant patent ducts arteriosus in premature infants. Acta Paediatrica. 2013; 102:e347-52.

26. Hsu JH, Yang SN, Chen HL, Tseng HI, Dai ZK, Wu JR. B-type natriuretic peptide predicts responses to indomethacin in premature neonates with patent ductus arteriosus. J Pediatr. 2010;157:79-84.

27. Lee JH, Shin JH, Park KH, Rhie YJ, Park MS, Choi BM. Can early B-type natriuretic peptide assays predict symptomatic patent ductus arteriosus in extremely low birth weight infants? Neonatology. 2013;103:118-22.

28. Elsayed Y, Dakshinamurti S, Soni R, Ruffo I, Seshia MM. Does serum brain natriuretic peptide (BNP) together with a novel PDA score improve PDA treatment selection? Pediatr Res. 2011;70:643. 